\title{
LATERAL FERRUGINOUS GROUNDWATER TRANSFER AS THE ORIGIN OF THE IRON CRUSTS IN CAVES: A CASE STUDY
}

\author{
Cristina Fonollá', , Eugenio Sanz ${ }^{1}$, and Ignacio Menéndez-Pidal ${ }^{1}$
}

\section{ABSTRACT}

The iron crusts appearing in all sections of the lower gallery of the Majada del Cura cave (Soria, Spain) consist of iron oxides, hydroxides, and to a lesser extent, manganese; the predominant mineral is goethite. The genesis of goethite is associated with the hydrogeomorphological evolution of the hypogeum river, which has received, upstream from explored cavities, lateral transfer of slightly ferruginous groundwater from the anaerobic environment of the Utrillas facies. The Utrillas facies connects to the cave only through the cave's lower gallery but not from the high gallery. Based on preexisting knowledge of the geomorphological history and the decrease in karstic base level, this connection has existed since at least the Middle Pleistocene. The torrential character of the river and the aerobic conditions cause precipitation by oxidation of $\mathrm{Fe}^{+2}$ with little bacterial participation, and the formation of mineral species is compatible with this oxidizing environment.

\section{Introduction and Objectives}

Iron and Manganese oxides and hydroxide deposits appear frequently in cavities (Hill and Forti, 1997), and the mineralogy of these deposits can be quite complex (Onac and Forti, 2011a; Post, 1999; White et al., 2009). In past decades, these types of speleothems have been studied in many cavities (among others: Crabtree, 1962; Moore, 1981; Gascoine, 1982; Hill, 1982; Kashima, 1983; Dyson and James, 1981; Peck, 1986; Onac and Forti, 2011b; White et al., 2009; Frierdich et al., 2011; Carmichael et al., 2013; Yusta et al., 2009; Rossi et al., 2010, Rossi et al., 2016; Gázquez et al., 2011; Gázquez et al., 2012). In those works, the incrustations are studied from different perspectives such as mineralogy, speleogenesis, and paleoenvironment. These works address the origin of the iron or manganese present in the crusts.

For a long time, it was thought that the formation of mineral deposits in caves and speleothems were mainly controlled by abiotic processes as a result of the cave's environmental conditions and changes in redox conditions (Barton and Northup, 2007; Engel et al., 2004; Northup and Lavoie, 2001). However, according to the most recent microbiological investigations, it has been proven that deposition of iron and manganese is often governed by microorganisms, mainly bacteria, which metabolize by the processes of $\mathrm{Fe}$ and $\mathrm{Mn}$ mobilization from sediments, as well as through oxidation and deposition (Skinner and Fitzpatrick, 1992; Hose et al., 2000; Sommers et al., 2002; Northup and Lavoie, 2001, Northup et al., 2003; Spilde et al., 2005; Boston et al., 2006, Boston et al., 2009; Hill and Forti, 2007; Hazel and Northup, 2007).

The objective of this work is the macroscopic, chemical, and mineralogical characterization of the iron and manganese crusts of the Majada del Cura cave. The cave's relationship with the hydrogeological and hydrogeochemical characteristics of the karst and the geological formations of the environment has allowed the construction of a genetic model of the crusts.

This work also aims to limit this model to the past as much as possible. For this, it has been fundamental to relate the regional external geomorphology to the altitudinal arrangement of caves and springs, as well as the altitudinal arrangement of sandy formations to ferruginous underground waters and the dating of calcareous tufa and cave sediments. Thus, the main characteristics of the paleohydrogeological evolution of the aquifer are determined, showing the relationship that this evolution has had with the hydrodynamics of the karstic aquifer and the formation of the iron crusts.

\section{Methodology}

During explorations of the Majada del Cura cave, different types of iron precipitates and their macroscopic characteristics have been described. Their distribution within the hydrological and sedimentological context of the karstic apparatus has been analyzed. The other known cavities of this Pico Frentes and Sierra Llana karst have also been explored (Fig. 2) in case they present similar ferruginous crusts.

To analyze the geochemistry and mineralogy of the iron crusts, five representative samples were taken, three of the patina of iron on pebbles (CF-1, CF-2 and CF-3), one of a crust on a speleothem (C-1) and another corresponding to a current precipitate (P1) in a puddle of overflow water (Fig. 4-F). Several analytical techniques were employed and are briefly described below. The quantitative chemical analyses of samples P1 and C1 were conducted through X-Ray

${ }^{1}$ Geology Laboratory. Department of Engineering and Land Morphology. Esc. Tec. Sup de Ing. de Caminos, C.C. y P.P. (School of Civil Engineering), UNIVERSIDAD POLITÉCNICA DE MADRID (U.P.M.), C/ Profesor Aranguren 3, 28040 Madrid, Spain

c Corresponding author: cristina.fonolla@upm.es 
Fluorescence (XRF), a multipurpose X-ray diffraction Panalytical with a Wavelength Dispersive X-ray Fluorescence (WDXRF) spectrometer. Results of the analyses are listed in Table 2. X-Ray Diffraction (XRD) equipment, "Bruker D8 Advance", for powder samples was used to identify the mineralogical composition of the crystalline phases present in the five samples (Table 1).

Since it was difficult to visually isolate the iron crusts completely from the surface on which they formed, the constituent minerals of the crusts and iron mineralization were identified through images (Fig. 4 to Fig. 6) obtained with a scanning electron microscope (SEM/EDS) model JEOL JSM-820 that has an energy-dispersive X-ray detector (EDX) attached. The EDX was used to perform semi quantitative analyses of several zones of the crusts and of the substrate in contact with the crusts. Microprobe analyses (Table 3) confirmed that the crusts also contained manganese oxides. All the analyses have been carried out in the Technical Services Area of the Complutense University of Madrid, (Spain).

Inside the active cave, the iron crusts have been deposited on the surfaces of all forms of karstic erosion, as well as in the current detrital sediments and in the ancient levels hung by paleogours associated with the subterranean river. In recognizing these sediments of detrital origin, recycled particles from the Utrillas facies were observed, which do not outcrop in the vicinity of the cave, suggesting that those particles have undoubtedly been transported upstream by the hypogeum river through conduits that are, for the moment, inaccessible. This issue was important because it has been known for a long time that this facies contains ferruginous groundwater in the area, and this could constitute the possible source of iron crust. Since there are no methods available to create boreholes, it has been studied first, and the descriptive geometry of the structural contour suggests the possibility that this facies was in depth in hydraulic connection with the cave. A hydrogeochemical study of the area around the karstic apparatus was initiated to evaluate the distribution and concentration of the ferruginous groundwater in these sedimentary facies that could explain the origin of the iron in the crusts. Chemical analyses were obtained from 140 boreholes and wells corresponding to the municipal areas of 10 population centers located in the lower parts of the mountain. The total iron concentration (iron in solution plus iron in suspension) present in these boreholes and wells was measured at the Territorial Service of the Ministry of Health in the province of Soria by the method of atomic absorption spectrophotometry (Servicio Territorial de Sanidad, 1995-1997). The iron content of the effluent streams that circulated during the dry season due to the Weald and Utrillas facies was also analyzed with portable field equipment.

Regarding the current iron precipitation processes, some specific measurements have been made in the underground river, in different hydrological conditions, on the iron content, $\mathrm{pH}$, electrical conductivity and temperature. A historical series of geochemical analyses of the Fuentetoba spring water measuring iron content have been conducted to determine whether they indicated significant concentrations.

To detect the possible presence of bacterial groups in the groundwater, as well as to determine the aggressiveness of these bacteria (indicated by the time it takes for the reaction to appear) and their possible influence on the formation of iron patinas of iron and manganese, tests were carried out following the B.A.R.T method (Biological Activity Reaction Tests) designed by Cullimore (1992). Tubes were used, each of which contained a crystallized pellet of chemicals at the bottom and a free sphere. A tube was filled with water to the upper mark $(15 \mathrm{~mL})$, causing the sphere to float and isolating the upper medium (aerobic) from the lower medium (anaerobic). For 15 days, the reactions that occurred in the water and in the pearl were observed (Table 4) and identified with those defined by the manufacturer.

On the walls cut by the erosion of the speleothems mentioned of paleogours, the alternation of clear and dark 1 millimeter calcite layers depending on their iron content were observed in detail. These layers revealed that the geochemical precipitation processes of the iron were associated with the river starting from past epochs to the present. It was interesting to date these chemical sediments, and, in this way, two samples were taken from the two levels of paleogours located at different heights, to determine their age as indicated by the decay of radioactive isotopes of uranium/thorium (U/Th) (Table 6). These tests have been carried out in the Institute of Earth Sciences "Jaime Almera" of the CSIC through ICP-MS (Hellstrom, 2003).

Table 1. Mineralogical semiquantitative analysis of mineral phases by dust XRD.

\begin{tabular}{|c|c|c|c|c|c|c|c|c|}
\hline \multirow[b]{2}{*}{$\begin{array}{c}\text { Sample } \\
\text { Name }\end{array}$} & \multicolumn{8}{|c|}{ Mineral Phases, \% } \\
\hline & Quartz & $\begin{array}{c}\text { Alkali } \\
\text { Feldspar }\end{array}$ & Phyllosilicates & Calcite & Goethite & Lepidocrocite & Hematite & Magnetite \\
\hline $\mathrm{C}-1$ & 58 & 11 & 25 & 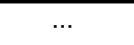 & 3 & 1 & 1 & 1 \\
\hline CF-1 & 46 & 5 & 12 & 24 & 10 & $\cdots$ & 2 & 1 \\
\hline CF-2 & 1 & $\cdots$ & $\cdots$ & 97 & 1 & $\cdots$ & $\cdots$ & 1 \\
\hline CF-3 & 49 & 11 & 20 & 17 & 1 & $\cdots$ & 1 & 1 \\
\hline$P-1$ & 66 & 5 & 14 & 1 & 11 & $\cdots$ & 2 & 1 \\
\hline
\end{tabular}


The characteristics of active and abandoned conduits and the integration of the external geomorphology with the dating of the paleogours terraces present in the cave with the underground river, and of the calcareous tufa associated with the upwellings, have contributed to a better understanding of the speleogenesis of the system and propose an evolution of the karstic aquifer. In this sense, the calcareous tufa of these springs have been sampled (Fig. 3A, Fig. 4 and Fig. 10A) to determine their age by U/Th by means of unbalance series. This was completed at the Institute of Earth Sciences "Jaime Almera" of CSIC through ICP/MS (Hellstrom, 2003).

\section{Geological, Geomorphological, and Hydrogeological Setting}

The Majada del Cura cave (UTM 30N European $1950 X(\mathrm{~m})=0533288$ long, $Y(\mathrm{~m})=4626421$ latitude) is found in the eastern end of the Sierra of Cabrejas, which belongs to the septentrional area of the Iberian Range (Soria, NE of Spain). The cave was discovered in 2002 by speleological groups Deportes Espeleo and Terrasub (Sanz et al., 2012), and it is still in the exploration phase. The cave's entrance is located in a high plateau at 1,240 m.a.s. (called Sierra Llana) and extends more than $3.5 \mathrm{~km}$ with an E-W direction (Fig. 1).

The explored cavities seem to present two macro-stages in the installation of the networks and phases of karstification. To these two macro-stages correspond at least the two levels of well-defined main galleries:

The first level of galleries and networks is hanging, made of fossil, predominantly horizontal, and has large dimensions. It is located near the level $(-20 \mathrm{~m})$ of the mouth of entrance or towards the height $1,220 \mathrm{~m}$.

In the second level, another active network links to the previous one through some galleries inclined at about forty degrees. This gallery is sub horizontal, and the channel of a hypogean river runs with a longitudinal slope inclined east towards its drainage point (Fuentetoba). It is a profile of successive backwaters and steps of rapids and waterfalls. We could place it towards the level $-50 \mathrm{~m}(1,190 \mathrm{~m})$.

From the stratigraphic point of view, the ancient materials in the area belong to the Weald facies (Lower Cretaceous), of detritic nature and about $300 \mathrm{~m}$ thick.

Above these sediments is a stratigraphic unit of the Middle Cretaceous, known as the "Utrillas facies." This facies is widespread in much of the Iberian Peninsula, and by extension this term is applied to the diachronic section that emerges throughout the Iberian Cordillera, which represents the sediments of predominantly fluvial facies Albian aged; although there were also marshy areas (lignites) and sediments of wind origin. The sediments of quartz sands predominate with a small proportion of feldspar grains that were subsequently altered to kaolin. At its base, part of the Aptian can be represented, and on its roof, the Cenomanian. It sits discordantly on Paleozoic, Triassic, Jurassic, or continental Lower Cretaceous ("Weald facies") materials and gives rise to a Regional Discontinuity Surface.

At this site, the Utrillas facies is $576 \mathrm{~m}$ thick, and it can be differentiated into two units: a lower unit containing $200 \mathrm{~m}$ of sandstone and a conglomerate domain over lutites, as well as an upper $376 \mathrm{~m}$ unit of medium thickness conglomerate sandstone layers interspersed in a thick series of lutites. These layers of thick sands to conglomerates are rich in quartz and K-feldspar, and its grey color results from large amounts of type I organic matter (lacustrine) in an immature state, but very close to the hydrocarbon generation window that fills the intergranular porosity. Normal samples have OIL $=1.5$ and almost $4.0 \mathrm{mg} / \mathrm{g}$ of rock of organic matter in the form of hydrocarbons in liquid state (Marfil et al., 1992). This tar sandstone was exploited as an asphalt mine (average content of $8 \%$ ) in the 19th and early 20 th centuries through a gallery up

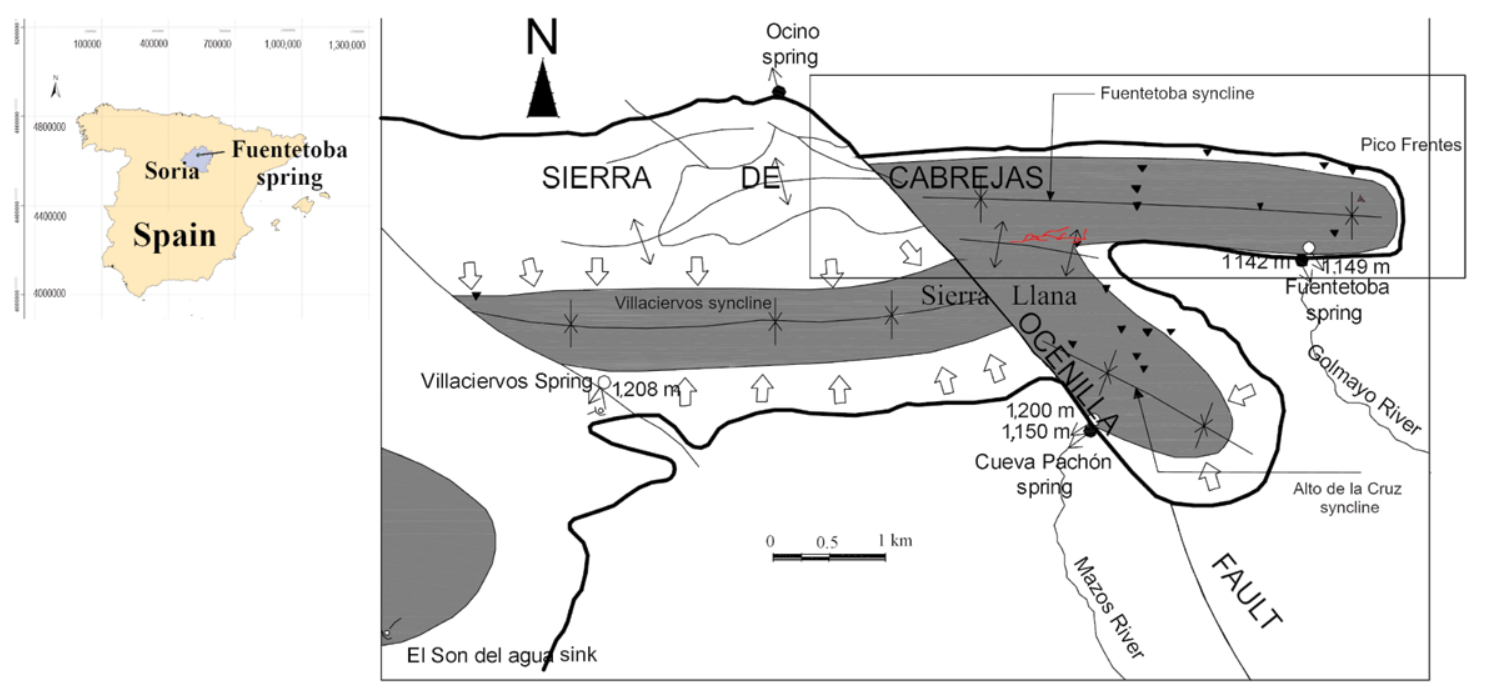

Figure 1. The Majada del Cura cave location map (Sanz et al., 2012). to $50 \mathrm{~m}$ deep in the core of the same anticline where Majada del Cura cave developed.

Both the Weald and the Utrillas facies have a similar hydrogeological behavior: they constitute a detritic aquifer where the numerous intercalations of lutites limit their permeability or confine it in some sectors. The presence of ferruginous cement in 
the sandstones is important, and ferruginous crusts of iron hydroxides associated with laminations and bedding surfaces are frequent (Fig. 10C). There are even small limonite and goethite deposits that have been exploited in the past and with local interest. All of this contributes to the fact that groundwaters are naturally contaminated by the presence of iron, which might jeopardize these geological formations as useful aquifers for human supply (Yélamos and Sanz, 1994; Sanz and Martínez, 2004). The iron content is related to the degree of aeration and oxygenation in aquifers: the upper part is hydrodynamically more active and aerobic; and therefore, has less iron (and vice versa). Likewise, the more permeable materials (more aerated) have less iron, and the less permeable ones have more iron. The iron content of the streams increases in the summer since in the dry season the underground component of the water currents has

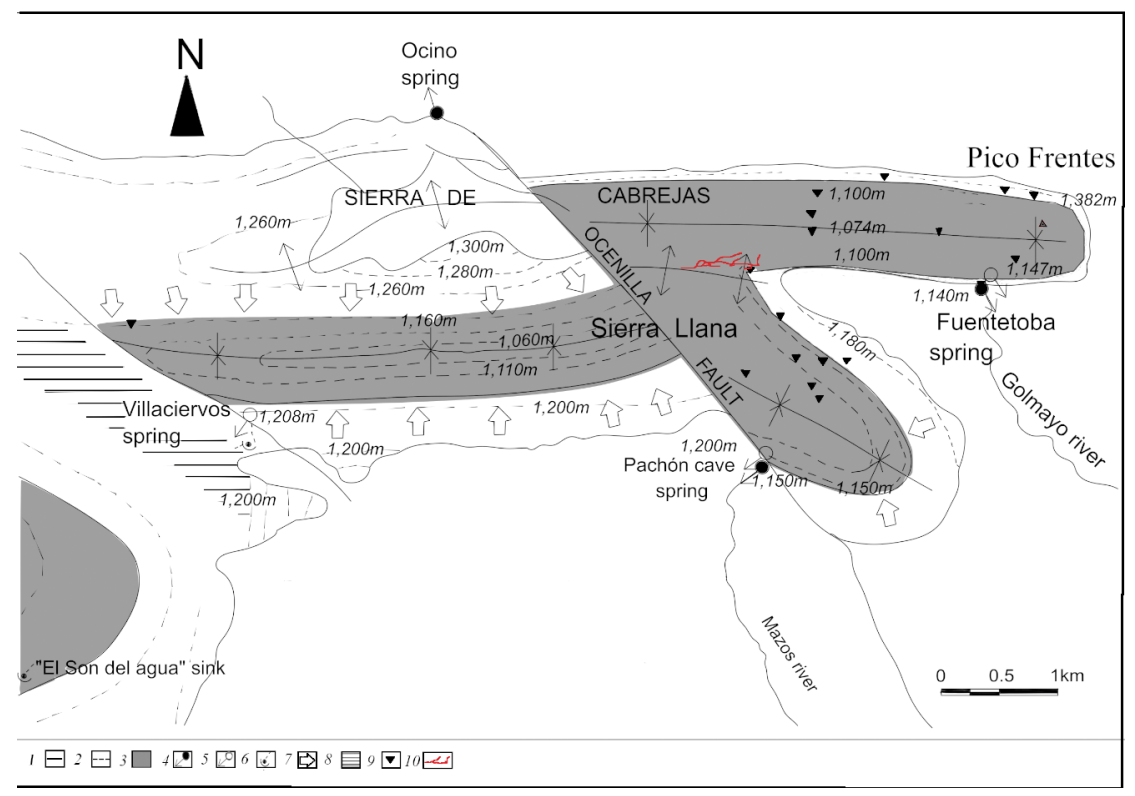

Figure 2. Hydrogeological organization of the karst system (Rosas et al., 2016). 1. Limestones-marls contact outcrop. 2. Contour lines limestones-marls contact in Pico Frentes aquifer. 3. Permanently saturated zone. 4. Spring, perennial. 5. Spring, intermittent. 6. Sink. 7. Groundwater flow in the peripheral of the saturation zone. 8. Groundwater divide. 9. Caves and potholes. 10. The Majada del Cura cave.

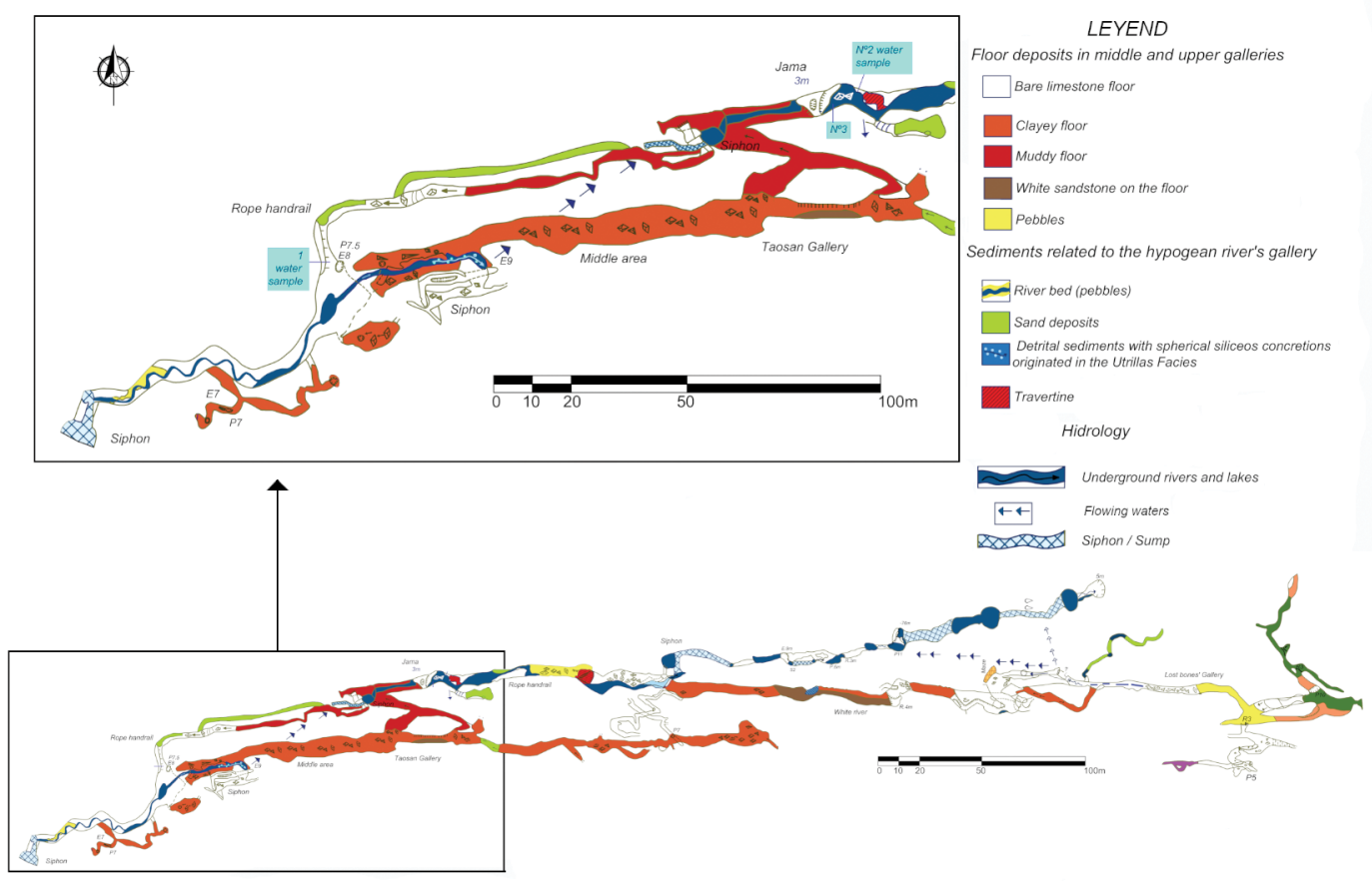

Figure 3. Current topography. La Majada del Cura cave (Soria). Ferruginous crusts are found in the active gallery. more influence (Sanz and Martínez, 2004).

Above the sands of the Utrillas facies is the Cenomanian limestone, which is more or less, sandy and marly; fossiliferous marls and clayey limestones Turonian aged serve as the impermeable base of the karst aquifer where the cave is located. Concordant with the Turonian are $100 \mathrm{~m}$ of Coniacian nodular limestones that, together with the $120 \mathrm{~m}$ thick massive Santonian-Campanian limestones, stand out morphologically in the relief, giving rise to the cliffs of the northern edge of the Pico Frentes and Sierra Llana. The cave is excavated in these carbonaceous rocks, perfectly following the direction and dip of the layers of geological contact between marls and limestones near the axis of an east-west direction anticline. These limestones make up the karstic aquifer of Pico Frentes (Rosas et al., 2016; Sanz et al., 2016), a highly developed karst system that is constituted by a succession of synclines displaced by the strike-slip Ocenilla fault (Fig. 2). The aquifer drains through the source of the Mazos river and

Fuentetoba spring. This last spring has about 200 $\mathrm{L} / \mathrm{s}$ of medium flow and is highly variable (Rosas et al., 2016).

It seems that the axis of the Fuentetoba anticline, at least from the Ocenilla fault, influences the hydrogeological organization of the karstic massif, contributing to the division of the drainage. In the north, the flow is directed towards Fuentetoba spring and in the south, towards the source of the Mazos river and other upwelling waters located at the head of the Golmayo river ravine.

The explored cavities present two levels of 
well-defined main galleries that are superimposed along the same geological contact that dips between $45^{\circ}$ and $65^{\circ}$ towards the north. The first gallery is a hanging, huge fossil and is predominantly horizontal. In the second level, an active network exists that links to the previous one through some inclined passages. This gallery is active and through it runs a hypogeum river with a slope inclined to the east, towards its drainage point (Fuentetoba spring). It is a profile of successive backwaters and steps of rapids and waterfalls (Figure 3).

The Sierra of Cabrejas, from a geomorphological point of view, was affected by a long stage of denudation during the Upper Neogene, with levelling and generalized flattening towards the 1,250m height, although with a gently dipping slope towards the south; It is an erosion surface of the Astaracian (Benito-Calvo and Pérez-González, 2007). Regionally, Benito-Calvo and Pérez-González (2007) locate the beginning of the exhumation of the previous surface; and therefore, the beginning of the incision of the drainage at the end of the Turonian. Late, on this surface, a relict or fossil surface drainage network was installed (Pliocene and throughout the Quaternary). It is shallow and incipient that is conserved notched in the rock in some areas. There are doline fields, some uvalas, and karren fields. The subsequent erosive phases led to the lowering of the relief of the limestone massif to the level $1,030-1,000 \mathrm{~m}$, which is the altitude of the Douro river to the north of this mountain range (Sanz, 1992).

\section{Results}

\section{Macroscopic description of iron crusts and their geological and hydrogeological context}

The iron and manganese crusts of the cave are located on floors, walls, and ceilings of the active gallery (they are not present in the upper gallery), continuously covering a large part of the surfaces with a thin black or brown layer between 0.01 and $4 \mathrm{~mm}$ thick. They occur mainly in the upstream westernmost part of the underground river, losing some importance in the eastern lower sector, according to groundwater flow direction. Through the course of the underground river and below the minimum low water level, no ferruginous incrustations are formed, and the rock appears nude with its natural cream color. The originating agent of the ferruginous incrustations is considered to be the river since the habitual levels of current floods are marked and distinguished by the different intensities of coloration on the channel walls, with the intensity increasing as the height of water increases (Fig. 4A). There are also horizontal paleo-levels located at higher elevations of the river and lakes, which sometimes number up to six. They are drawn by horizontal lines of iron oxides on the walls that indicate the successive pulses of embedding of the river. At some points, the dark deposits of iron have fallen off.

Ferruginous precipitates constitute crusts of consolidated material. Their surface is smooth and adapts to all kinds
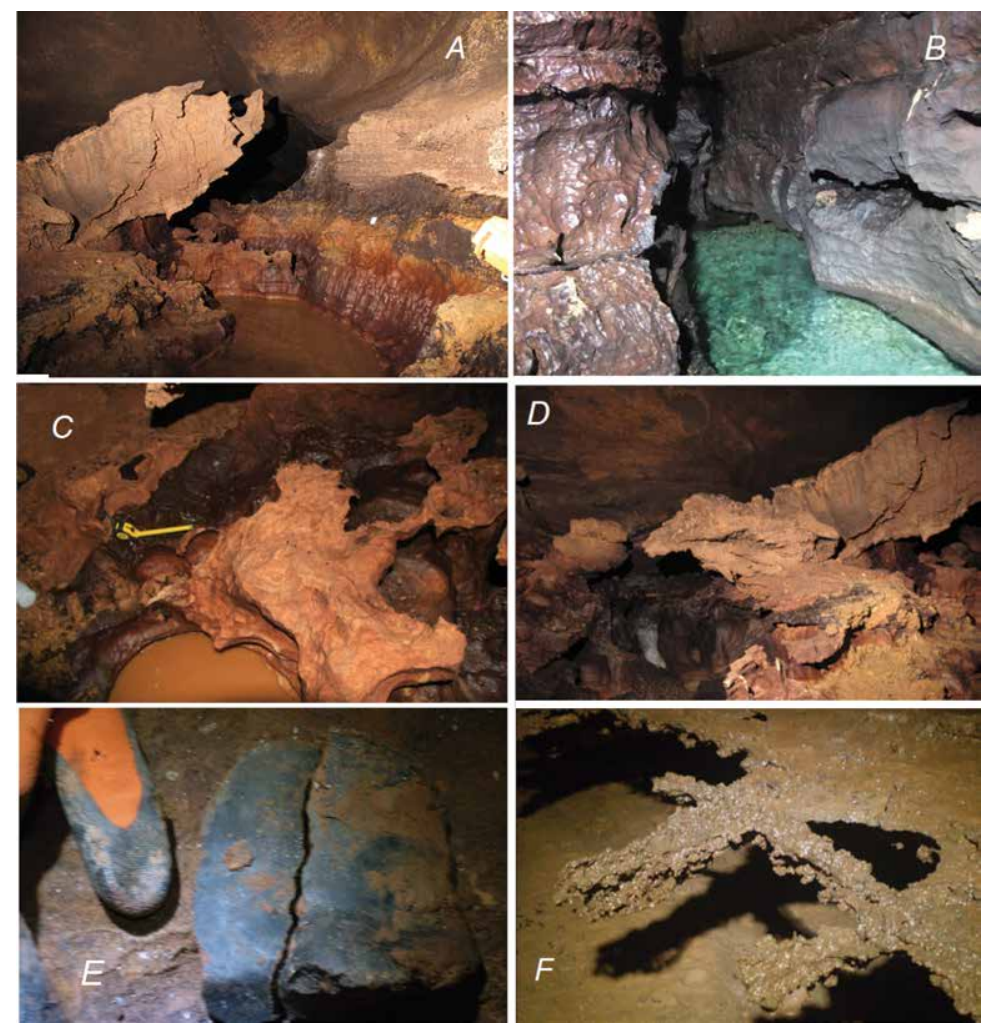

Figure 4. Ferruginous crusts and deposits in the active gallery of The Majada del Cura cave. of erosion forms and sediments (from the past and present) in the active cave. Some different types of sediments include:

1. Fine sheets of iron covering forms of corrosion in the substrate rock (Fig. 4B).

2. Patches of black crust of $1-2 \mathrm{~cm}$ on the surfaces of paleogours. From here sample C-1 was taken (Fig. 4C).

3. Iron sheets of 0.1 to $2 \mathrm{~cm}$ covering a huge yellow clay lump no more than $5 \mathrm{~cm}$ thick attached to the walls of the gallery and located at different heights and with variable dimensions that are related to recent floods (Fig. 4D).

4. Pebbles covered in a black patina on the outer side of $1 \mathrm{~mm}$ thick (Fig. 4E). It affects gravels and pebbles deposited between clays corresponding to sediments of recent floods located between the current channel level and up to $1 \mathrm{~m}$ above. From here, the samples CF-1, CF-2 and CF-3 were taken.

5. Ferruginous precipitates associated with current stagnant flood waters located $1 \mathrm{~m}$ above the current channel. They are lattices of calcite and floating iron supported on the edges of the banks (Fig. 4F). From here, the sample P-1 was taken. 

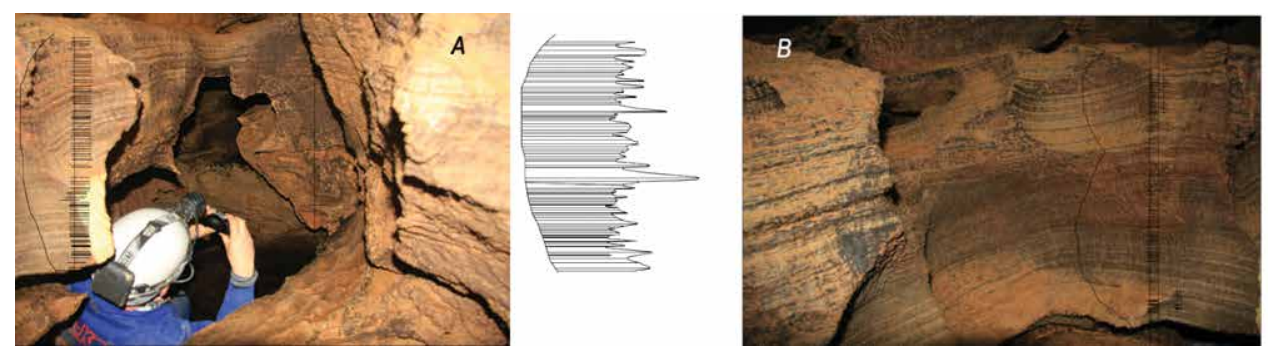

In the erosion sections of potholes that affect paleogours, in the small layers of growth of these speleothems, an alternation of light 1 millimeter layers of calcite and other dark layers with higher iron content are observed. This different content of iron is superficially revealed in a

patent manner (Fig. 5A). Figure 5. Iron-Mn external lamination in gours. 5A Fresh section of the gours (above the helmet) does not exhibit Fe-Mn lamination. Fig. 5B Potholes have affected paleogours.

The clear layers of calcite are thicker, about 5 or 6 times more than dark layers. With cuts of $0.5 \mathrm{~m}$ in Figure $5 \mathrm{~A}, 65$ tiny layers can be counted, and in Figure 5B with cuts of $5 \mathrm{~m}, 99$ tiny layers can be counted.

\section{Geochemical and mineralogical results of iron crusts}

Semi quantitative mineralogical analyses of the five samples by powder XRD were used to detect the crystalline phases of iron oxides and hydroxides, hematite (1-2\%), goethite (1-11\%), magnetite (1\%), and lepidocrocite (1\%). Due to the low crystallinity of the crusts, the X-ray diffractograms were poorly defined. Other minerals present included quartz, potassium feldspar, and phyllosilicates (clay minerals) (Table 1).

Iron and manganese oxides have been detected in the crusts by means of X-ray fluorescence in samples C1 (paleogours) and P1 (Table 2); the percentages of manganese in the total sample are small. However, higher values have been detected in the punctual analysis of the cortices with the EDX microprobe in all samples (Table 3).

The samples of pebbles collected in the current river have crusts of iron oxides (77.73 - 4\%) and manganese (25.72$10.47 \%$ ), and their chemical composition varies depending on the area of the crust where the microanalysis was carried out. Some crusts have formed on carbonate clasts (CF-2 and CF-3) and others on clay minerals, quartz, and feldspars (CF-1).

In the area outside the paleogours (sample C1, Fig. 6-B), a network of filaments was observed that covers the surface of the sample, probably belonging to ferruginous bacteria, and rounded deposits that may be the result of their biological activity. In a cross-section, the chemical composition of the crust was analyzed with a microprobe that detected a matrix of iron and manganese oxides, with clay and quartz minerals that include quartz clasts (samples C13-SP1 to SP5). The composition of the material in contact with the crust of iron includes iron oxides, alumina-silicates, and quartz.

The last sample analyzed (P-1) is formed by iron and manganese oxides with quartz fragments in some areas, depending on where the analysis was carried out. Rounded goethite textures were photographed. An orange paste of clay minerals, iron oxides, and quartz was deposited on the iron crusts (Figures 6 to 8).

\section{Result on the current presence of iron bacteria}

The cultures used were I.R.B (iron related bacteria), S.L.Y.M. (slime forming bacteria), T.A.H. (total aerobic bacteria) and S.R.B. (sulfate reducing bacteria). The reactions that occurred are summarized in Table 4 . The $1 \mathrm{HAB} / \mathrm{TAB}$ reaction indicates the existence of aerobic bacteria, with a population $<61,000 \mathrm{cfu} / \mathrm{mL}$ (cfu $=$ cells) and moderate activity. The I.R.B have a population $<10 \mathrm{cfu} / \mathrm{mL}$ and are not aggressive; reaction $\mathrm{n}^{\circ} 5$ indicates the existence of anaerobic Ferro-bacteria. The SLYM tubes contain general microflora, and its population of $500-2500 \mathrm{cfu} / \mathrm{mL}$ is moderate. Finally, the current sulfate reducing bacteria (S.R.B) from the water samples in zones Z2 and Z3 have a population of less than $20 \mathrm{cfu} / \mathrm{mL}$, so they are considered non-aggressive. However, in zone 1, the population between the values of 925 to $1400 \mathrm{cfu} / \mathrm{mL}$ indicate a medium aggressiveness (Senderos, 2001), (Smith, 1995).

\section{Results of chemical analyses of iron in the waters of the underground river and Fuentetoba spring}

It has not been possible to perform periodic monitoring in the underground river and overflow ponds because of accessibility difficulties, but some specific measures carried out in two overflow ponds and in the hypogeum river (zones 1-3 of Fig. 3) of the active gallery of the cave do not present high concentrations of iron (Table 5). The pH is slightly alkaline, and

Table 2. Analysis of oxides in weight percentage of samples $\mathrm{C} 1$ y P1, XRF.

\begin{tabular}{|c|c|c|c|c|c|c|c|c|c|c|c|c|c|c|c|c|c|c|c|}
\hline \multirow{2}{*}{$\begin{array}{c}\text { Sample } \\
\text { Name }\end{array}$} & \multicolumn{19}{|c|}{ Oxides } \\
\hline & $\mathrm{Fe}_{2} \mathrm{O}_{3}$ & $\mathrm{CaO}$ & $\mathrm{SiO}_{2}$ & $\mathrm{MgO}$ & $\mathrm{Al}_{2} \mathrm{O}_{3}$ & $\mathrm{~K}_{2} \mathrm{O}$ & $\mathrm{Na}_{2} \mathrm{O}$ & $\mathrm{Cr}_{2} \mathrm{O} 3$ & $\mathrm{MnO}$ & $\mathrm{TiO}_{2}$ & $\mathrm{~V}_{2} \mathrm{O}_{5}$ & $\mathrm{SnO}_{2}$ & $\mathbf{P}_{2} \mathbf{O}_{5}$ & $\mathrm{SrO}_{2}$ & $\mathrm{ZrO}_{2}$ & $\mathrm{SO}_{3}$ & $\mathrm{Cl}$ & $\mathrm{ZnO}$ & $\mathrm{CoO}$ \\
\hline $\mathrm{C} 1$ & 11.17 & 0.99 & 62.14 & 1.10 & 19.52 & 3.11 & 0.30 & 0.01 & 0.12 & 0.90 & 0.04 & $\ldots$ & 0.25 & $\cdots$ & 0.11 & 0.08 & 0.08 & 0.01 & 0.01 \\
\hline P1 & 32.54 & 1.37 & 51.93 & 0.50 & 9.83 & 1.44 & 0.20 & 0.20 & 0.62 & 0.79 & 0.03 & 0.01 & 0.30 & $\ldots$ & 0.26 & 0.05 & 0.07 & 0.01 & $\ldots$ \\
\hline
\end{tabular}




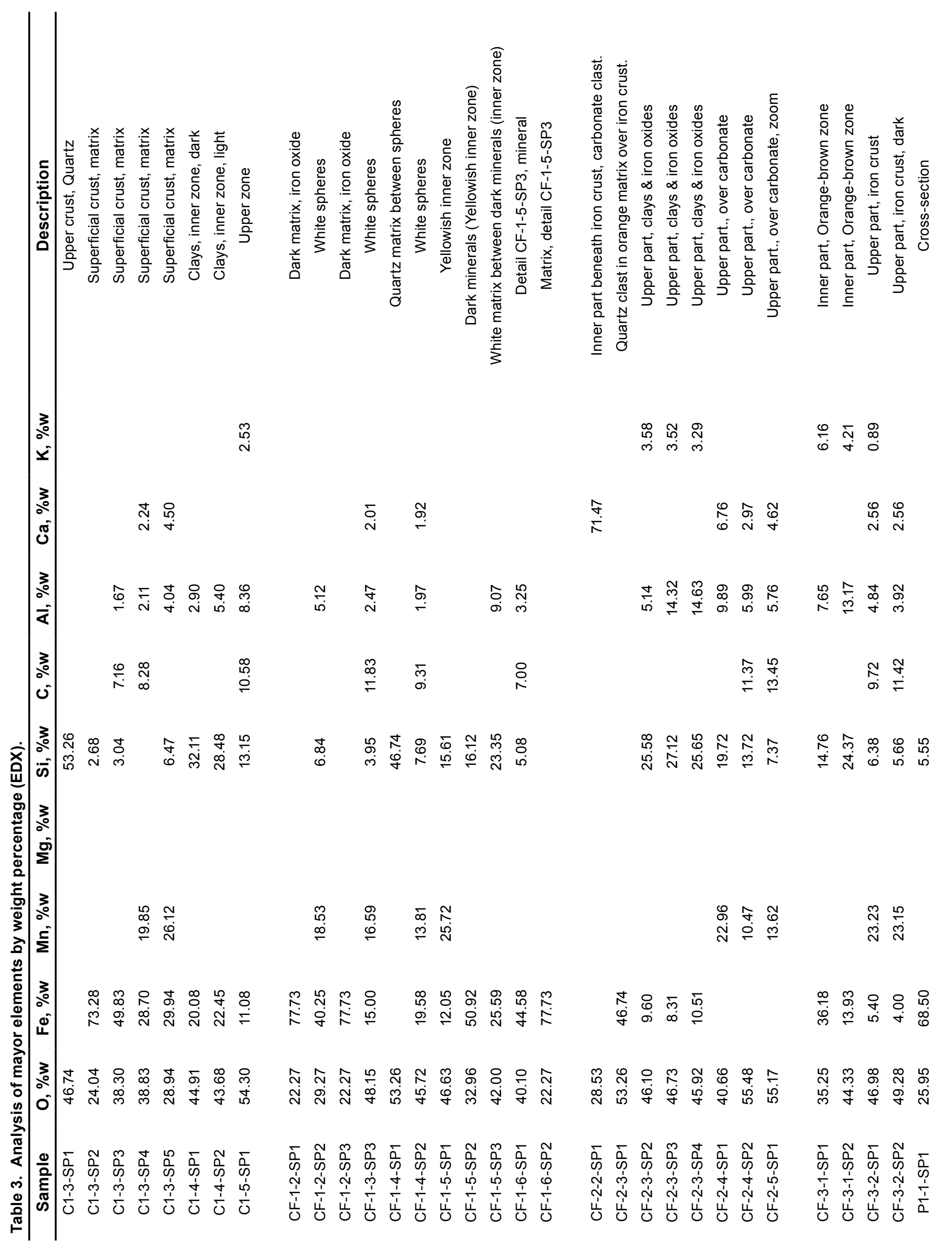




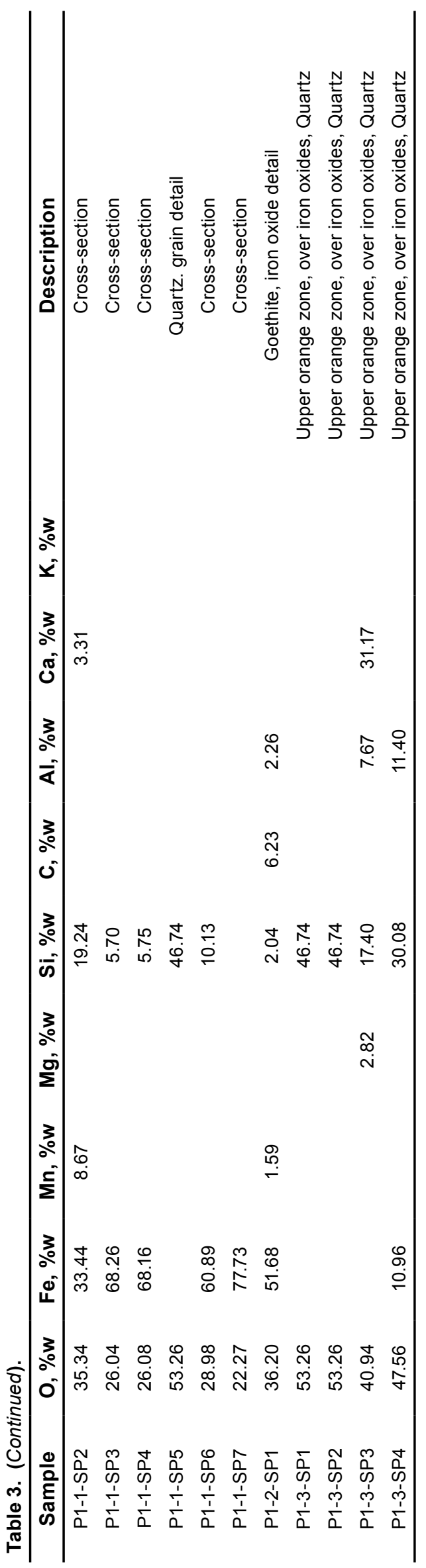

the river temperature is about $8^{\circ} \mathrm{C}$. The conductivity of the river is $300 \mu \mathrm{S} / \mathrm{cm}$, and the conductivity of lakes is $700 \mu \mathrm{S} /$ $\mathrm{cm}$. The measurements in Fuentetoba spring have been more continuous. The Fuentetoba spring is the point of exit of the underground river and located $2 \mathrm{~km}$ to the west of this known stretch of cave. There have been 23 semester chemical analyses throughout 2001- 2018 (CH Duero). According to these analyses, the water is calcium-bicarbonate facies and poorly mineralized, where bicarbonates (between $200 \mu \mathrm{g} / \mathrm{L}$ and $42 \mu \mathrm{g} / \mathrm{L}$ ) and calcium (between 43 and $97 \mu \mathrm{g} / \mathrm{L}$ ) represent more than $95 \%$ of the ionic content. During certain summer months, the iron concentration can range from as high as $100 \mu \mathrm{g} / \mathrm{L}$ to less than $0.01 \mathrm{~g} / \mathrm{L}$. Of all the ions present in the water, the concentration of the iron ion shows the most pronounced seasonal variation. It should be noted that the analyzed iron is in solution and not of total iron, which is probably greater, as is the case with the results of the analysis of the water points located in the geological facies of Weald and Utrillas. The sulphate content varies from between 4 to $12 \mu \mathrm{g} / \mathrm{L}$. The conductivity normally ranges from between 300 to $400 \mu \mathrm{S} / \mathrm{cm}$, the temperature from between $7^{\circ} \mathrm{C}$ to $13^{\circ} \mathrm{C}$ and the $\mathrm{pH}$ from between 7.3 to 8.4 (Table 5).

\section{The ferruginous groundwaters of the Utrillas and Weald facies}

It has not been possible to obtain information from an immediate borehole to the cave, but it is possible to collect samples from the area around the karstic system of Pico Frentes. There is only a relatively close borehole that reaches the Utrillas, crossing the limestone of the Pico Frentes syncline and detecting ferruginous waters.

As shown on Figure 9, the presence of iron in the groundwater of the Facies Utrillas and Weald is widespread. Since a significant part of the registered water points (at least $30 \%$ of the boreholes) presents significant quantities of iron at almost $25 \%$ above $200 \mu \mathrm{g} / \mathrm{L}$, which marks the limit of potability for human consumption according to the current Spanish regulations, the iron is a real problem when looking for human supply captures in the area (Fig. 10). Results of dissolved iron concentrations in the water show that they range between a minimum value of $0 \mathrm{mg} / \mathrm{L}$ and a maximum of $22.7 \mathrm{mg} / \mathrm{L}$ of total iron, depending on the depth of the borehole and the underlying lithology. In addition, there are several streams that drain these facies and present ferruginous water in low water level.

Another interesting aspect is that the concentration of iron increases with the depth of circulation of the groundwater due to the lower presence of dissolved oxygen. This causes water's oxidation potential to decrease and reduced iron species to predominate, which do not precipitate easily due to their high solubility. This makes the water of the streams have less iron content than the springs and less iron than the water extracted from the boreholes via wells or pumping. In addition, in these boreholes, it has been possible to establish how the iron increases up 


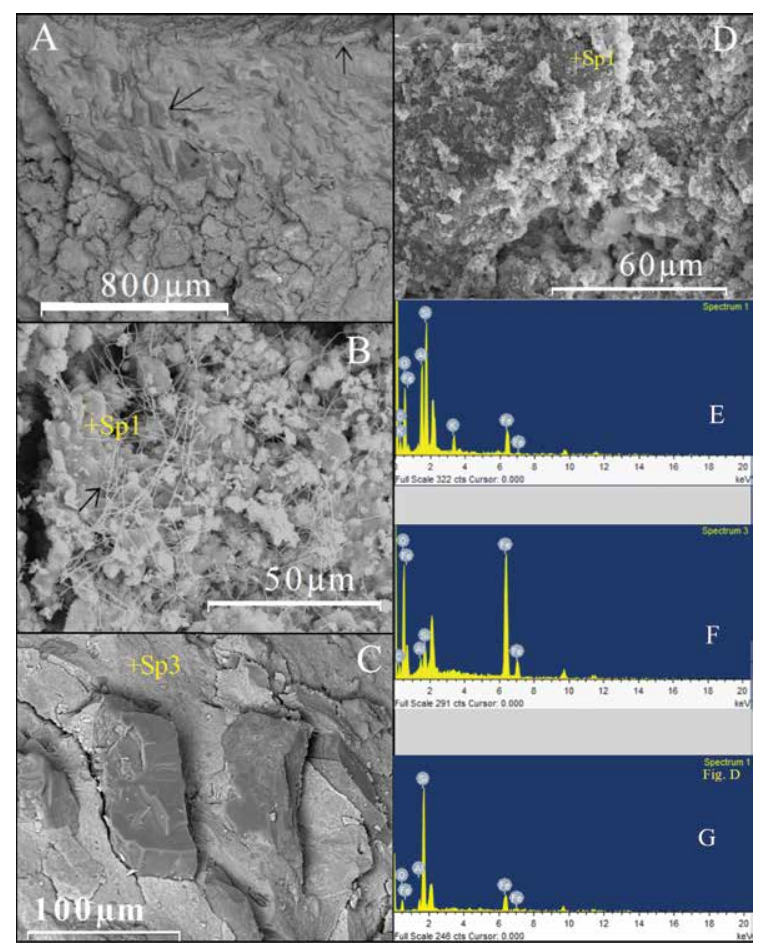

Figure 6. Group of documentary photos: (A) Photographs of a section of the paleogours crusts, sample C1, (B) outer surface of the bark with filaments belonging to bacteria, sp1 EDX micro analysis (E), (C) Most inner zone of the crust, with quartz clasts embedded in a matrix of iron oxides and aluminium-silicates ( EDX analysis in F). (D) Internal, granular zone composed of oxides of Fe, Si and clays. In (G) sp1 EDX microanalysis. to $50 \mathrm{~m}$, as seen in the map of the Figure 9, reaching values of up to $20 \mu \mathrm{g} / \mathrm{L}$ of total iron. The content of iron also varies seasonally, depending on whether the water is low or high, so that iron increases in low waters where the influence of groundwater discharges in Utrillas and in Weald. The iron content is greater in the springs, especially in the streams. This has also been observed in Fuentetoba spring.

\section{The hydraulic connection of the Utrillas facies with the active gallery of the Majada del Cura cave in depth}

The $40 \mathrm{~m}$ vertical displacement of the Ocenilla fault allows the deep intersection of the Utrillas facies of the footwall block of the west with the karstified limestones of the hanging wall block. Much of this underground intersection is located in the saturated zone and allows the hydraulic connection between these two hydro-stratigraphic formations of different permeability along two short sections ( $400 \mathrm{~m}$ approximately in total) that are deduced by means of descriptive geometry and represented schematically (Fig. 2). Prolonging the gallery according to its westward direction following the stratification planes on which it faithfully fits, the western end of the active gallery is located at about $300 \mathrm{~m}$ of distance of the stretch of the fault, where the deep Utrillas facies are foreseeably located. This stretch of cave is still unexplored and may be inaccessible, but it is where the water flow comes from. This connection between the Utrillas and the cave has been verified in a reliable way by the existence of sediments from the deposits of avenues of the cave's underground river, where most sediments are limestone sands, although $10 \%$ are highly abrasive sands and pebbles of quartz and quartzite, exactly like those of the Utrillas facies. In addition, some spherical nodules of quartz aggregates only appear in this stratigraphic facies (Fig. 10-A).

\section{Ancient deposits of the river with the presence of iron}

On the outside of the karstic system, the limestones precipitated in Fuentetoba spring are a reddish color, and this is a sign of the presence of iron in its waters. Nevertheless, inside the cave, there are speleothems of paleogours, and when the speleothems have been eroded alternating clear and dark 1 millimeter calcite layers, with lower and higher
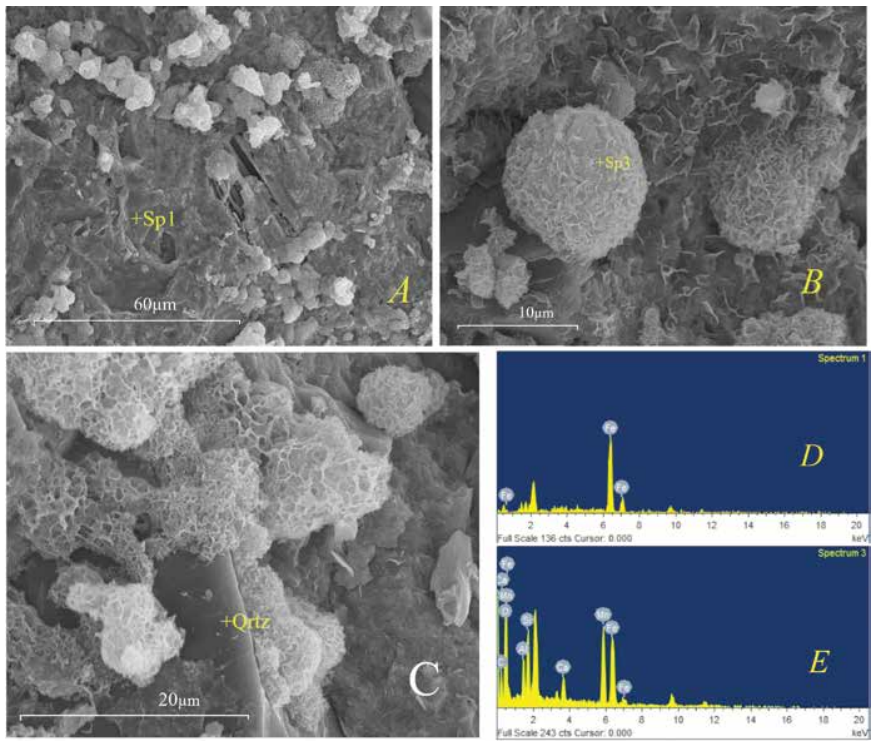

Figure 7. .Sample CF-1 Photographs of SEM (A) general view of the crust section, dark matrix of Fe oxides, EDX analysis at (D), (B) expansion of the Fe and Mn oxide spheres, composition in the EDX (E) microanalysis; (C) detail of a quartz crystal surrounded by $\mathrm{Fe}$ and $\mathrm{Mn}$ oxides. iron content respectively, are observed. In the past, each waterfall jump conditioned the formation of gours barriers, leading to a lacustrine phase more important than the current one, with the succession of lakes one after the other. Some of these gours barriers subsist half eroded, but others have been hung as terraces, or as rock ledge, well welded to the walls of the sections cut in later erosive phases. The lower active network of the river cave has two generations of dripstone stalagmite located between 0.5 and $5 \mathrm{~m}$ above the current channel and associated with gours barriers. They appear as two levels of terraces, especially on the current steps or slope breaks where there are cascades and waterfalls and where the agitation of the water favored the precipitation of calcium carbonate.

Two samples with $\mathrm{U} / \mathrm{Th}$ have been dated, one corresponding to a low-intermediate paleogours terrace where the contamination by Th 232 is relatively low and constitutes a reliable data (sample $n^{\circ} .1$ of Table 6). Sample $N^{\circ} .2$ is from a high terrace of paleogours, and its age exceeds the limit of the method of $>350,000$ years. These crusts bear witness to an old encrusting circulation corresponding to $188,000 \mathrm{BP}$ on the lower terrace and more than $350.00 \mathrm{BP}$ on the upper 

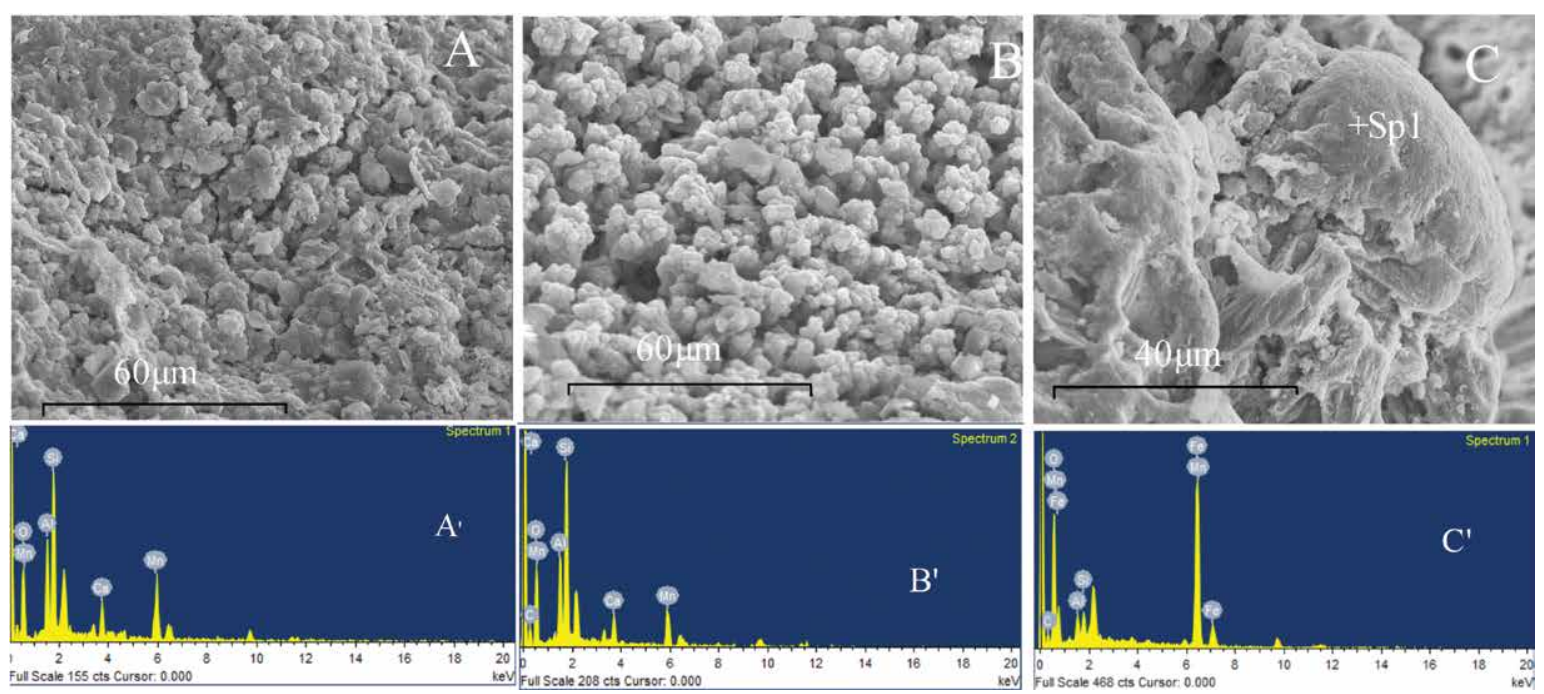

Figure 8. Photographs SEM (A) sample pebble CF-2 ridge oxides from the inner zone of the crust, in contact with the carbonate, EDX analysis (A'). (B) CF-3 ridge Fe and Mn oxides, EDX microanalysis (B'), (C) shows P-1 crystal detail of goethite (goethite), (C') EDX microanalysis. calcareous tufa of the Mazos river and contaminated by Th232. Therefore, the value of the dating is approximate. However, sample No. 4 is slightly contaminated, collected in the calcareous tufa of La Monjía, and located a few hundred meters from Fuentetoba spring. At a higher level, they are also part of Fuentetoba spring and gives an age close to the method limit $>350,000$ years. Finally, the sample No. 10A was collected in the calcareous tufa next to Fuentetoba spring. Based on analysis, it gives an age of 252,304 years $+70,511 /-42,615$.

Other samples taken contained so much residue that it was impossible to date them. These included samples from the calcareous tufa of Pachón cave, the spring of the Mazos river (sample No. 11B) and a column of clay located in an intermediate section of the second level of the Majada del Cura cave.

Table 4. B.A.R.T. tests results for selected sampling stations.

\begin{tabular}{|c|c|c|c|c|c|c|c|c|}
\hline \multirow[b]{3}{*}{ Sample Name } & \multicolumn{8}{|c|}{ Reaction and Days to Reaction } \\
\hline & \multicolumn{2}{|c|}{ I.R.B. } & \multicolumn{2}{|c|}{ S.L.Y.M. } & \multicolumn{2}{|c|}{ T.A.B. } & \multicolumn{2}{|c|}{ S.R.B. } \\
\hline & Reaction & Day & Reaction & Day & Reaction & Day & Reaction & Day \\
\hline Rope handrails - Z.1 & 5 & 10 & $\mathrm{~N}$ & $\mathrm{~N}$ & 1 & 3 & 2 & 6 \\
\hline 'Algaes'- Z.2 & $\mathrm{N}$ & $\mathrm{N}$ & 3 & 6 & 1 & 3 & $U$ & $U$ \\
\hline Hypogean river -Z.3 & $\mathrm{N}$ & $\mathrm{N}$ & 2 & 5 & 1 & 3 & $\mathrm{~N}$ & $\mathrm{~N}$ \\
\hline \multicolumn{9}{|c|}{$\begin{array}{l}\text { Note: Samples were collected in spring time. } \\
\text { No reaction }=\mathrm{N} \\
\text { Reaction unknown }=U\end{array}$} \\
\hline \multicolumn{9}{|c|}{$\begin{array}{l}\text { Table 5. Temperature, } \mathrm{pH} \text { and iron concentration from water samples collected from La Majada del Cura } \\
\text { cave (Spain). }\end{array}$} \\
\hline \multicolumn{2}{|c|}{ Sample name } & \multicolumn{3}{|c|}{ Temperature, ${ }^{\circ} \mathrm{C}$} & $\mathrm{pH}$ & \multicolumn{3}{|c|}{ Iron concentration, ppm } \\
\hline \multicolumn{2}{|c|}{ Rope handrails - Z.1 } & \multicolumn{3}{|c|}{11.4} & 7.30 & \multicolumn{3}{|c|}{0.00} \\
\hline \multicolumn{2}{|l|}{ 'Algaes'- Z.2 } & \multicolumn{3}{|c|}{11.4} & 7.25 & \multicolumn{3}{|c|}{0.00} \\
\hline \multicolumn{2}{|c|}{ Hypogean river - Z.3 } & \multicolumn{3}{|c|}{10.9} & 7.24 & \multicolumn{2}{|c|}{$0.40^{a}$} & $0.00^{\mathrm{b}}$ \\
\hline
\end{tabular}

Table 6. Values of U/Th dating of two paleogours levels from The Majada del Cura cave (Spain).

\begin{tabular}{cccccccc}
\hline $\begin{array}{c}\text { Sample } \\
\text { Name }\end{array}$ & Ref - Lab & U-238, ppm & Th-232, ppm & U-234/U-238 & Th-230/Th-232 & Th-230/U-234 & Nominal Date, BP \\
\hline 1 & 1512 & 0.29 & 0.10 & $1.11 \pm 0.02$ & $8.596 \pm 0.458$ & $0.84 \pm 0.03$ & $188,808+17,060$ \\
& & & & & & $-14,853$ & \\
2 & 2712 & 0.25 & 0.38 & $1.01 \pm 0.03$ & $2.011 \pm 0.065$ & $0.97 \pm 0.04$ & $>350,000$ \\
\hline
\end{tabular}


Table 7. Values of U/Th dating of samples, calcareous tufa from Soria (Spain), 2012.

\begin{tabular}{|c|c|c|c|c|c|c|c|c|}
\hline $\begin{array}{l}\text { Sample } \\
\text { Number }\end{array}$ & & Ref - Lab & $\begin{array}{c}\text { U-238, } \\
\text { ppm }\end{array}$ & $\begin{array}{c}\text { Th-232, } \\
\text { ppm }\end{array}$ & $\begin{array}{l}\mathrm{U}-234 / \\
\mathrm{U}-238\end{array}$ & $\begin{array}{l}\text { Th-230/ } \\
\text { Th-232 }\end{array}$ & $\begin{array}{c}\text { Th-230/ } \\
\text { U-234 }\end{array}$ & $\begin{array}{c}\text { Nominal Date, } \\
\text { BP }\end{array}$ \\
\hline $3 A$ & Tufa-Mazos River & 1612 & 0.32 & 0.16 & $1.04 \pm 0.02$ & $1.953 \pm 0.082$ & $0.30 \pm 0.01$ & $\begin{aligned} 38,858 & +1,660 \\
& -1,635\end{aligned}$ \\
\hline 4 & Tufa-La Monjía & 1412 & 0.35 & 0.20 & $1.08 \pm 0.02$ & $5.808 \pm 0.232$ & $0.98 \pm 0.03$ & $\begin{array}{r}335,683+98,854 \\
-52,534\end{array}$ \\
\hline $10 \mathrm{~A}$ & Tufa-Fuentetoba spring & 3312 & 0.34 & 0.33 & $1.01 \pm 0.02$ & $2.927 \pm 0.186$ & 0.05 & $\begin{aligned} 252,304 & +70,511 \\
& -42,615\end{aligned}$ \\
\hline
\end{tabular}

\section{Discussion}

\section{Hydrogeochemical model of the crust's formation.}

As it is known, the main source of iron and manganese in karst comes from the host rock or the surrounding lithologies that contain these elements, which have been transported to the caves by water. The greatest variety of iron

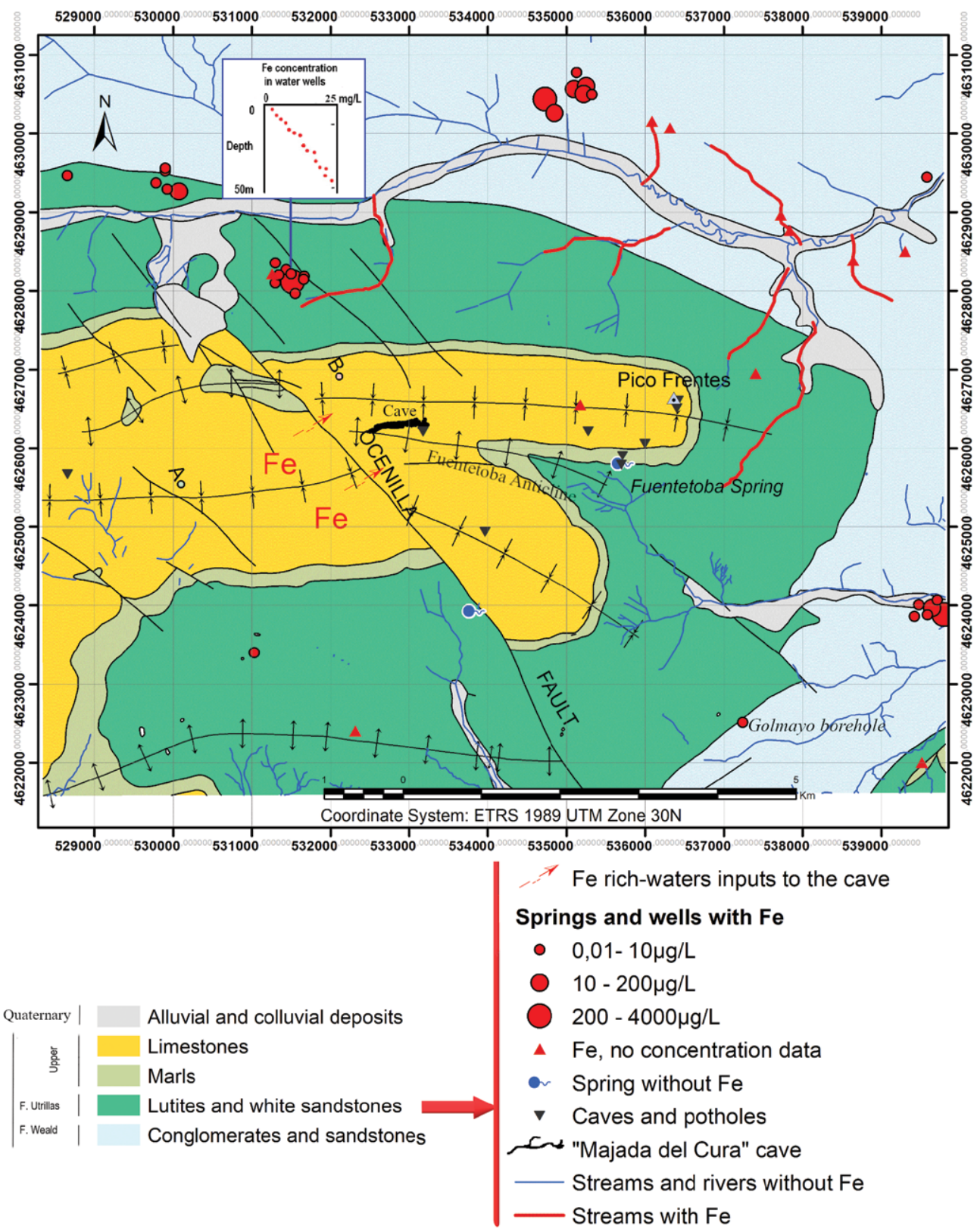

Figure 9. Hidrogeologycal map simplified from "Geological map hoja $n^{\circ} 349$, Cabrejas del Pinar (MAGNA)", springs and wells contain ferruginous water in Facies Weald and Utrillas. and manganese compounds are produced in carbonate rocks since these rocks and the products of their weathering ("terra rossa" in Mediterranean climates, for example) are enriched in minerals with iron and manganese. This is more unusual in other lithologies, such as gypsum, where the allochthonous origin is more frequent (Osborne, 1978; Peck, 1986; Bosák et al., 2002). Kashima (1983) mentions several caves where the manganese comes from alteration soils that have then been transported by infiltration. In Pauler Cave (Illinois, USA), iron and manganese deposits are deposited by filtrations and streams (Frierdich et al., 2011). Gascoine (1982) locates the origin of iron and manganese in the schists that are above the limestone of the cave and that, due to being transported by water, suffer oxidation near the input points. In Lechuguilla Cave (USA), water entering the cave as filtration is a potential source of dissolved manganese (Levy, 2007). Moore (1981) studies the case where the source of manganese is the reduced waters outside the cave due to the presence of vegetable particles. The origin of the manganese and iron that 


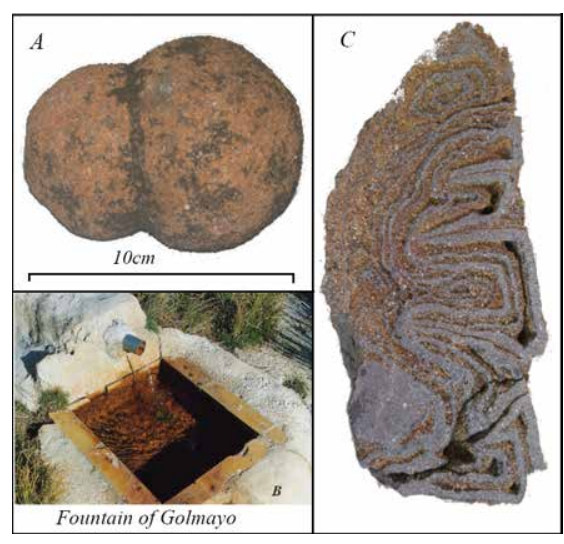

Figure 10. (A) Quartz nodules from Utrillas Facies, are transported by the hypogean river. (B) Ferruginous water from an artesian well in Utrillas Facies (Golmayo, Soria). (C) Convolute ferruginous lamination found in the Utrillas Facies.

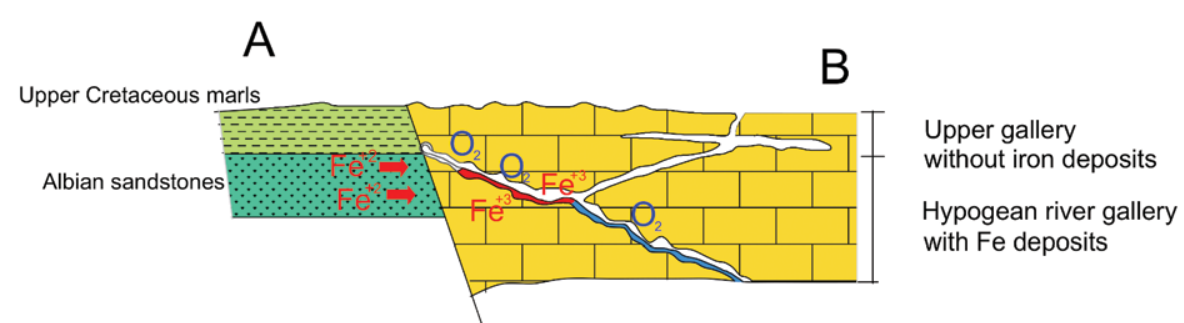

Figure 11. Cross section, footwall (A) Utrillas' sandstones seep water with $\mathrm{Fe}^{2+}$ into an oxidizing environment, downstream, to the limestones hanging wall $(B)$ where $\mathrm{Fe}^{3+}$ will precipitate in form of oxides-hydroxides of iron.

gave rise to the formation of the crusts of El Soplao Cave is related to the mobilization of these metals, present in the polymetallic sulphide mineralization of the host rock (Rossi et al., 2010). In other cases, the source is siderite nodules in limestones (Yusta et al., 2009). White et al. (2009) quotes pebble patinas of $\mathrm{Mn}$ and Fe that come from enrichment of $\mathrm{Mn}$ content in streams coming from upstream in non-karstic basins (Northup, 2003). On other occasions, these deposits are the result of enrichment of $\mathrm{Fe}$ and $\mathrm{Mn}$ through microbial oxidation of leachate from altered bedrock. In other words, they are a result of microbial alteration of the bedrock in vadose conditions. In coastal environments, Allouc and Harmelin (2001) attributes the origin of the biosedimentary deposits of $\mathrm{Mn}$ from the interaction of silt with microorganisms and $\mathrm{Mn}$ dissolved in seawater. The formation of microbial ferromanganesiferous Frutexites is also mentioned due to the entry of Fe and Mn rich freshwaters into submarine caves (Guido et al., 2016).

In contrast to studies of caves in other regions, the example explained here has the source of $\mathrm{Fe}$ in the transfer of ferruginous groundwater from a detrital aquifer in hydraulic connection with the Majada del Cura cave.

The abundance of iron precipitates in the Majada del Cura cave does not occur in the other caves and shafts of this karst system or in others in the region. In addition, the characteristics of the terra rossa, an underdeveloped soil with poor plant cover present outside this and the rest of the other caves, do not seem to favor the export of the $\mathrm{Fe}^{2+}$ ion. Apparently, there are no other possible sources of iron within karst systems in the area, such as mineralization in known iron deposits or elevated metal contents in the Cretaceous limestones. However, the presence of iron in this cave is not surprising since this cave is the only one that seems to be linked to the mobilization of the ferruginous underground water, with high concentrations associated with the sediments of the Facies Utrillas that, as it has been seen, have been in hydraulic connection with the active gallery through the Ocenilla fault at about 40-50 m deep. For this reason, the high gallery located above this level had no possibility of this iron source; and therefore, lacks iron crusts. As the hypogean network was fitted with time throughout the evolution of the karst, the gallery was connected with the Utrillas until the present. It must be admitted that this hydrogeochemical process is relatively modern within the speleogenetic context of the system, whose beginning dates back to the Miocene (Sanz et al., 2012) but includes at least the Middle Pleistocene until today, as it is deduced from the level and chronology of paleogours levels with speleothems influenced by the ferruginous environment.

The trace of this cave should be extended upstream, adjusting to the Ocenilla's fault plane, redirecting flows from the Villaciervos syncline and acting as the Utrillas reception gallery at a depth where it is assumed to be under anoxic conditions. Apart from the very ferruginous groundwater incorporated into the river, there is a possibility that these facies provide sands and particles of iron ores in the flood drains of the river. From another point of view, both these sandy sediments and the ferruginous waters of the Utrillas facies also behave in some way as natural water tracers in the groundwater low of the karstic system.

In the precipitation of iron, the chemical composition of the water is a determining factor, in that some units of parts per million of iron in solution assure the formation of scale, and small changes in the $\mathrm{pH}$ can favor it. In the few analyses carried out in situ in the stream during low water, no significant concentrations of iron have been detected, but this does not mean that there are not any in other situations or within the inaccessible upstream conducts, closer to the facies Utrillas and where a greater influence of ferruginous discharges to the system is expected. The high iron content sporadically detected in the outlet water of the karst system in Fuentetoba spring indicates that inside the karst system, there must be important entries of ferruginous waters. In fact, although the concentration of iron is not very high, it is enough to cause the precipitation of scales and crusts.

Although the chemical composition is very important, it is not the only factor, since in our case, it is also influenced by the torrential regime of the underground river and its great speed, turbulence, and water aeration in cascades and 
waterfalls that favor the release of carbon dioxide and the water oxygenation, favoring the precipitation of iron carbonates and hydroxides, respectively. This underground torrent acts as a real oxygenation reactor of the aquifer, stirring the water at high speed, favoring air-water contact, and producing a mechanism of natural de-ironing of the water with more soluble $\mathrm{Fe}^{2+}$ from the Utrillas upstream. $\mathrm{Fe}^{3+}$ will precipitate completely in the form of ferric hydroxide, provided that the water is around $\mathrm{pH}=8$ under aerobic conditions (which is the case). The presence of goethite as the most abundant mineral in iron crusts and other mineral species of iron oxides, such as hematite and magnetite, is perfectly compatible with this oxidizing environment (Fig. 11).

Thus, under these conditions, autoxidation of iron occurs, changing from soluble to insoluble forms.

For example, in the case of oxidation of the ferrous bicarbonate, soluble in the presence of water and in an aerobic medium, it passes to $\mathrm{Fe}$ III hydroxide, insoluble (only soluble with $\mathrm{pH}<2$ ):

$$
2 \mathrm{Fe}\left(\mathrm{HCO}_{3}\right)_{2}+\mathrm{H}_{2} \mathrm{O}+1 / 2 \mathrm{O}_{2} \rightarrow 2 \mathrm{Fe}(\mathrm{OH})_{3}+4 \mathrm{CO}_{2}
$$

This reaction is modified (adapted) from Cullimore \& McCann (1977).

$2 \mathrm{Fe}\left(\mathrm{HCO}_{3}\right)_{2}$ is soluble, while $\mathrm{Fe}(\mathrm{OH})_{3}$ is only soluble with $\mathrm{pH}<2,2$

In the same way, soluble manganese can be insolubilized:

$$
2 \mathrm{Mn}\left(\mathrm{HCO}_{3}\right)_{2}+\mathrm{O}_{2}+2 \mathrm{H}_{2} \mathrm{O} \rightarrow 2 \mathrm{Mn}(\mathrm{OH})_{4} \downarrow+4 \mathrm{CO}_{2} \uparrow
$$

The fluctuation of the hypogean river level reaches over $1.5 \mathrm{~m}$ in some areas. These variations have been, and are, important, as observed directly. In periods of high rainfall, ponds and siphons are filled, and there are larger discharges in the Fuentetoba spring. When the level of the hypogean river goes down, the water of the wet walls and the flood ponds evaporates, favoring the precipitation of carbonates and the oxidation of iron in the form of sheets and crusts on the walls and on the pebbles and sediments dragged in by the water.

It is widely known that iron and manganese compounds are extremely sensitive to changes in $\mathrm{pH}$ and Eh in water environments, and they oxidize when geochemical conditions change from anaerobic to aerobic, resulting in mineral precipitation (Skinner and Fitzpatrick, 1992). This can happen under natural conditions or by anthropogenic action. An example of this is the precipitates that iron and manganese biochemists provoked by mining activity, which occurred in the cave area of Zoloushka (Ukraine/Moldova), where the works of drainage in a gypsum quarry meant the opening of a karst aquifer and the consequent hydrogeochemical changes in the water environment of a cave (Kotula et al.,2019). Our case is somewhat similar, but due to natural causes: a detrital aquifer with ferruginous groundwater under anaerobic conditions since it is isolated from the surface by impermeable layers. The aquifer drains locally through a cave of a karstic aquifer that it is in contact with. It is assumed that this implies radical changes in the hydrogeochemical environment, which goes from reduction in the detrital aquifer to oxidative conditions within the cave.

In the past, during the middle and lower Pleistocene, and in at least two warm periods where the underground river flow was precarious, the generation of gours was favored. These speleothems developed in environments influenced by the ferruginous environment of the Utrillas since the level has barely changed by a few meters compared to the current channel. The enrichment of the iron by clear seasonal influence is observed, in such a way that the thinner and darker layers in the surface by oxidation of the iron carbonates (sample 5) were deposited safely in low water, when the water of the gours would be with less volume, supersaturated, and in a more oxidizing medium, although it is supposed to be a more toxic medium with the precipitation of iron carbonate (siderite) colorless. The subsequent exudation of iron, or the oxidation of the siderite, make it migrate to the surface, enriching itself in oxides of iron from siderite.

$$
2 \mathrm{Fe}\left(\mathrm{HCO}_{3}\right)_{2}+\mathrm{H}_{2} \mathrm{O}+1 / 2 \mathrm{O}_{2} \rightarrow 2 \mathrm{Fe}(\mathrm{OH})_{3}+4 \mathrm{CO}_{2}
$$

\section{The geomorphological evolution and the presence of iron crusts in the caves}

A period of several million years separates us from the generating processes of this cave, combining the syngenetic and paragenetic galleries inside the same underground network. In fact, a slow movement of age surely fini-tertiary period modelled a paragenetic gallery with dense red clay filling. Over time, in these paragenetic galleries, the circulation of water would disappear due to the lowering of the phreatic level, and they were suspended on other new synergic galleries re-excavated and active. During the initial stages, the underground flow was above the sands with ferruginous groundwaters of the Utrillas facies that did not intervene in the hydrogeological scheme. But once the karstic base level was lowered, the connection was made effective through the low gallery.

When did this hydraulic connection start? It is unknown with precision, but it can be affirmed that it is determined by the age of the paleogours and the calcareous tufa associated with the upwelling of Fuentetoba that has worked as an upwelling zone related to low galleries until now. The flow has been directed and concentrated towards the lower area of the south flank of the permeable contact syncline (limestone) and waterproof (Turonian marls). The Fuentetoba spring is currently the lowest point of this contact, and it should have remained the main point of stable drainage throughout much of the Quaternary period. Only here do the calcareous tufa deposits not exist in the entire northern flank and 
the rest of the periclinal closure, where the contact is at the highest level. Therefore, this upwelling should have been selected from at least the Middle Pleistocene and shows the large volume of calcareous tufa associated. Therefore, the formation of the crusts should be related to this final paleohydrogeological phase. The depth of the hypogeum river between the paleogours terraces dating from 188,000 BP and the current course does not usually exceed $4 \mathrm{~m}$, which indicates the little incision of the river.

\section{Conclusions}

Most of the origin of crusts and inlays of iron in the caves are associated with sources with rocks or nearby mineral deposits with high iron content, but in the case studied, it is a transfer of ferruginous water from an anaerobic environment that, due to a tectonic accident, passes to the underground river of a cave. The aeration of water by the torrential character of the hypogeum river favors the chemical precipitation in oxidizing medium of oxides and hydroxides of iron. This process has only worked from the hydraulic connection of the network of active lower galleries with the sands with ferruginous groundwaters of the Utrillas facies since at least the Middle Pleistocene, where the hydrogeological configuration was similar to the current one.

\section{Acknowledgements}

The authors thank Dr. Ing. Ruíz Bustinza for facilitating RX fluorescence analysis of samples P1 and C-1. In addition, we thank the Research Group of Geology Applied to Civil Engineering (VAGI18ESP project) for their help.

We want to thank the group of speleologists who collected the samples, without whom this study could not have been done, especially Carlos Morón and Javier G. Yélamos. We thank Carlos Pascual for the calcareous tufa sampling and Pablo Rosas for his contribution in the gours drawings and suppling information about the study area. We thank Ignacio Manuel Hernández, who provided us a calibrated portable pH-meter (E.T.S.I. Caminos - U.P.M. - Sanitary Engineering Lab.).

Finally, we thank anonymous reviewers who provided us observations and recommendations which have been helpful for improving our paper.

\section{References}

Allouc, J., and Harmelin, J. G., 2001, Mn-Fe deposits in shallow cryptic marine environment: Examples in Northwestern Mediterranean submarine caves: Bulletin de la Société Geologique de France, v. 172, p. 765-778. https://doi.org/10.2113/172.6.765

Barton, H.A., and Northup, D.E., 2007, Geomicrobiology in cave environments: Past, current and future perspectives: Journal of Cave and Karst Studies, v. 69, p. 163-178.

Benito-Calvo, A., and Pérez-González, A. ,2007. Erosion surfaces and Neogene landscape evolution in the NE Duero Basin (north-central Spain): Geomorphology, v. 88, Issues 3-4, p. 226-241. https://doi.org/10.1016/j.geomorph.2006.11.005.

Beltrán Cabrera, F.J., Ríos Mitchell, J.M., and Ríos Aragüés, L.M., 1980. Mapa Geológico de la hoja no 349, Cabrejas del Pinar. IGME Escala 1:50.000, Shape files.

Bosák, P., Bella, P., Cilek, V., Ford, D.C., Hercman, H., Kadlec, J., Osborne, A., and Pruner, P., 2002, Ochtiná Aragonite Cave (Western Carpathians, Slovakia): Morphology, Mineralogyof the Fill and Genesis: Geologica Carpathica, v. 53, p. 399-410.

Boston, P.J., Spilde, M.N., Northup, D.E., Rosales-Lagarde, L., and Stafford, K., 2006, Subsurface sulfur systems: Production and preservation of distinctive biogenic signatures in sulfur, iron, manganese, and carbonate cave systems: Geochimica et Cosmochimica Acta, v. 70, p. A60, https://doi:10.1016/j.gca.2006.06.225

Boston, P.J., Spilde, M.N., Northup, D.E., Curry, M.C., Melim, L.A., and Rosales-Lagarde, L. 2009. Microorganisms as speleogenetic agents: Geochemical diversity but geomicrobial unity, in, Klimchouk, A.B. and Ford, D.C., eds., Hypogene Speleogenesis and Karst Hydrology of Artesian Basins, Ukrainian Inst. Speleology and Karstology Special Paper 1, p 51-58.

Carmichael, M.J., Carmichael, S.K., Santelli, C.M., Strom, A., and Bräuer, S.L., 2013, Mn (II)-oxidizing Bacteria are Abundant and Environmentally Relevant Members of Ferromanganese Deposits in Caves of the Upper Tennessee River Basin: Geomicrobiology Journal, v. 30, p. 779, https://doi.org/10.1080/01490451.2013.769651

CH Duero (Confederación Hidrográfica del Duero) http://www.mirame.chduero.es/DMADuero_09_Viewer/viewerShow.do;jsessionid=C0858653A78DE4AA03598E6B84E6C3F2?action=showViewer

Crabtree, P.W., 1962. Bog ore from Black Reef Cave: Cave Science, v. 4, p. 360-361.

Cullimore, D.R., and McCann,1977, The Identification, Evolution and Control of Iron bacteria, in Skinner, F.A. and Sewan, J.M., eds., Groundwater, Aquatic Microbiology: New York, Academic Press, p. 219-261.

Cullimore, D.R., 1992, Practical Manual of Groundwater Microbiology, Lewis Publishers, 412 p.

Dyson, H.J., and James, J.M., 1981, The incidence of iron bacteria in an Australian cave, in Beck, B.F. ed., Proceedings of the 8th International Congress of Speleology, v. 1, p. 79-81.

Engel, A.S., Stern, L.A., and Bennett, P.C., 2004, Microbial contributions to cave formation: New insights into sulfuric acid Speleogenesis: Geology, v. 32, p. 369. https://doi:10.1130/G20288.1

Frierdich, A.J., Hasenmueller, E.A., and Catalano, J.G., 2011, Composition and structure of nanocrystalline Fe and Mn oxide cave deposits: Implications for trace element mobility in karst systems: Chemical Geology, v. 284, p. 82-96. https://doi.org/10.1016/j.chemgeo.2011.02.009

Gascoine, W., 1982. The formation of black deposits in some caves of South East Wales. Cave Science, v. 9, no. 3, p. $167-175$.

Gázquez, F., Calaforra, J.M., and Forti, P., 2011, Black Mn-Fe Crusts as Markers of Abrupt Palaeoenvironmental Changes in El Soplao Cave (Cantabria, Spain): International Journal of Speleology, v. 40, p. 163-169, https://doi:10.5038/1827-806X.40.2.8

Gázquez, F., Calaforra, J.M., and Rull, F., 2012, Boxwork and ferromanganese coatings in hypogenic caves: An example from Sima de la Higuera Cave (Murcia, SE Spain): Geomorphology, v. 177-178, p. 158-166. https://doi.org/10.1016/j.geomorph.2012.07.022 
Guido, A., Rosso, A., Sanfilippo, R., Russo, F., and Mastandrea, A., 2016, Frutexites from microbial/metazoan bioconstructions of recent and Pleistocene marine caves (Sicily, Italy): Palaeogeography, Palaeoclimatology, Palaeoecology, v. 453, p. 127-138. https://doi:10.1016/j.palaeo.2016.04.025

Hellstrom, J. ,2003. Rapid and accurate U/Th dating using parallel ion-counting multi-collector ICP-MS: Journal of Analytical Atomic Spectrometry, v. 18, p. 1346-1351. https://doi.org/10.1039/B308781F

Hill C.A., 1982, Origin of black deposits in caves: National Speleological Society Bulletin, v. 44, p. 15-19.

Hill, C.A., and Forti, P., 1997, Cave minerals of the World 2: National Speleological Society.

Hill, C.A., Forti, P., 2007, Cave mineralogy and the NSS: Past, present, future: Journal of Cave and Karst Studies, v. 69, p. $35-45$.

Hose, L.D., Palmer, A.N., Palmer, M.V., Northup, D.E., Boston, P.J., and DuChene, H.R., 2000, Microbiology and geochemistry in a hydrogen-sulphide-rich karst environment: Chemical Geology, v. 169, p. 399-423. https://doi:10.1016/S0009-2541(00)00217-5

Kashima, N., 1983, On the wad-minerals from the cavern environment: International Journal of Speleology, v. 13, p. 67-71. http://dx.doi. org/10.5038/1827-806X.13.1.5

Kotula, P., Andreychouk, V., Pawlyta, J., Marynowski, L., and Jendrzejewska, I., 2019, Genesis of iron and manganese sediments in Zoloushka Cave (Ukraine/Moldova) as revealed by $\delta 13 \mathrm{C}$ organic carbon: International Journal of Speleology, v. 48, p. 221-235. https://doi. org/10.5038/1827-806X.48.3.2255

Levy, D.B., 2007, Oxidation-reduction chemistry of Lechuguilla Cave seepage: Journal of Cave and Karst Studies, v. 69, p. 351-358.

Marfil, R., Callaba, A., Gómez-Gras, D., 1992, Materia orgánica en la Fm. Arenas de Utrillas de Picofrentes (provincia de Soria): diagénesis mineral y orgánica: Geogaceta, v. 12, p. 43-46.

Moore, G.W., 1981. Origin of black deposits in caves, in Proceedings 8th International Congress of Speleology, Bowling Green I and II, p. 642-644.

Northup, D.E. and Lavoie, K.H., 2001, Geomicrobiology of Caves: A Review: Geomicrobiology Journal, v. 18, p. 199-222. https:// doi:10.1080/01490450152467750

Northup, D.E., Barns, S.M., Yu, L.E., Spilde, M.N., Schelble, R.T., Dano, K.E, Crossey,

L.J., Connolly, C.A., Boston, P.J., Natvig, D.O. and Dahm, C.N., 2003, Diverse microbial communities inhabiting ferromanganese deposits in Lechuguilla and Spider Caves: Environmental Microbiology, v. 5, p. 1071-1086. https://doi.org/10.1046/j.1462-2920.2003.00500.x

Onac, B.P., and Forti, P., 2011a, Minerogenetic mechanisms occurring in the cave environment: An overview: International Journal of Speleology, v. 40, p. 79-98. http://dx.doi.org/10.5038/1827-806X.40.2.1

Onac, B.P., and Forti, P., 2011b, State of the art and challenges in cave minerals studies. Studia UBB Geologia, v. 56, no. 1, p. $33-42$. https:// doi.org/10.5038/1937-8602.56.1.4

Osborne, R.A.L., 1978, Structure, Sediments and Speleogenesis at Cliefden Caves, New South Wales: Helictite, v. 16, no. 1, p. 3-32.

Peck, S.B., 1986, Bacterial deposition of iron and manganese oxides in North American caves: National Speleological Society Bulletin, v. 48, no. 1, p. 26-30.

Post, J.E., 1999, Manganese oxide minerals: Crystal structures and economic and environmental significance, in Proceedings of the National Academy of Sciences of the United States of America, v. 96, p. 3447-3454. https://doi.org/10.1073/pnas.96.7.3447

Rosas, P., Sanz, E., and Menéndez-Pidal, I., 2016, Hidrogeología del Karst de Pico Frentes (Cordillera Ibérica, España): Estudios Geológicos, v. 72, no 1, p. 1-21. https://doi.org/10.3989/egeol.42132.375

Rossi, C., Lozano, R.P., Isanta, N., and Hellstrom, J., 2010, Manganese stromatolites in caves: El Soplao (Cantabria, Spain): Geology, v. 38, p. 1119-1122. https://doi:10.1130/G31283.1

Rossi, C., Villalaín, J.J., Lozano, R.P., and Hellstrom, J., 2016, Paleo-watertable definition using cave ferromanganese stromatolites and associated cave-wall notches (Sierra de Arnero, Spain): Geomorphology, v. 261, p. 57-75. https://doi:10.1016/j.geomorph.2016.02.023

Sanz, E., 1992, Relieve de la Sierra de Cabrejas. III Congreso geológico de España y I Congreso geológico iberoamericano de Geología: Salamanca, tomo, v. 3, p. 91-95.

Sanz, E., and Martínez, A., 2004, Hidroestratigrafía e hidrogeoquímica de la Facies Weald del Noroeste de la Cordillera Ibérica (Región de Pinares, Soria), VIII Simposio de Hidrogeología. Asociación Española de Hidrogeólogos. Zaragoza (España), p 155-164.

Sanz, E., López, J., Meneses, J.M., and Menéndez-Pidal, I., 2012, Guía geológica de la Sierra de Cabrejas y del Monumento Natural de la Fuentona (Soria) Diputación Provincial de Soria: Colección Temas Sorianos.

Sanz, E., Rosas, P., and Menéndez-Pidal, I., 2016, Drainage and siphoning of a karstic spring: A case study: Journal of Cave and Karst Studies, v. 78, no, 3, p. 183-197. https://doi:10.4311/2015ES0134.

Senderos, A. J., 2001, Estudio microbiológico de las incrustaciones y corrosiones en captaciones de agua subterránea: Universidad Complutense de Madrid. Facultad de Ciencias Geológicas. Tesis.

Servicio Territorial de Sanidad (Soria),1995-1997, Analítica de puntos de agua de la provincia de Soria.

Skinner, H.C.W., and Fitzpatrick, R.W., 1992, in Skinner, H.C.W. and Fitzpatrick, R.W. eds., Biomineralization processes of iron and manganese: modern and ancient environments: Caten Supplements, v. 21, p. 1-6.

Smith, S., 1995. Monitoring and Remediation Wells: Problem, Prevention, Maintenance and Rehabilitation: New York, Lewis Publishers, 183 p.

Sommers, M.G., Dollhopf, M.E., and Douglas, S., 2002, Freshwater Ferromanganese Stromatolites from Lake Vermilion, Minnesota: Microbial Culturing and Environmental Scanning Electron Microscopy Investigations: Geomicrobiology Journal, v. 19, p. 407-427, https:// doi:10.1080/01490450290098513

Spilde, M.N., Northup, D.E., Boston, P.J., Schelble, R.T., Dano, K.E., Crossey, L.J., and Dahm, C.N., 2005, Geomicrobiology of Cave Ferromanganese Deposits: A Field and Laboratory Investigation: Geomicrobiology Journal, v. 22, p. 99-116, https://doi:10.1080/01490450590945889

White, W.B., Vito, C., and Scheetz, B.E., 2009, The mineralogy and trace element chemistry of black manganese oxide deposits from caves: Journal of Cave and Karst Studies, v. 71 no. 2, p. 136-143.

Yélamos, J.G. and y Sanz, E., 1994, Hidrogeoquímica de los manantiales sulfhídricos y ferruginosos de las facies Purbeck-Weald del noroeste de la Cordillera Ibérica (provincia de Soria): Estudios Geológicos, v. 50, no. 3-4 . https://doi.org/10.3989/egeol.94503-4319

Yusta, I., Castellano, A., Aranburu, A., and Velasco, F., 2009, Los depósitos de Mn-Al-Fe de la cueva de Lazalday (Zarate, Álava): composición química y mineralogía: Geogaceta, v. 47, p. 117-120. 